\title{
An Ethylene Over-Producing Mutant of Tomato (Solanum lycopersicum), Epinastic, Exhibits Tolerance to High Temperature Conditions
}

\author{
Sridharan Jegadeesan 1,2, Etan Pressman1, Avital Beery'1, Vikram Singh1, \\ Lázaro Eustáquio Pereira Peres ${ }^{3}$, Sara Shabtai', Nurit Firon ${ }^{1 *}$ \\ ${ }^{1}$ Department of Vegetable and Field Crops, Institute of Plant Sciences, Agricultural Research Organization, The Volcani Center, \\ Rishon LeZion, Israel \\ ${ }^{2}$ Field Application Scientist, Premas Life Sciences, Bangalore, India \\ ${ }^{3}$ Laboratory of Hormonal Control of Plant Development, Departamento de Ciências Biológicas, Escola Superior de Agricultura \\ "Luiz de Queiroz", Universidade de São Paulo, Piracicaba, Brazil \\ Email: jsri.86@gmail.com, pressman@volcani.agri.gov.il, avitalb@volcani.agri.gov.il, vikram.s.viking@gmail.com, \\ lazaro.peres@usp.br, sara_shabtai@walla.co.il, ^vcfiron@volcani.agri.gov.il
}

How to cite this paper: Jegadeesan, S., Pressman, E., Beery, A., Singh, V., Peres, L.E.P., Shabtai, S. and Firon, N. (2021) An Ethylene Over-Producing Mutant of Tomato (Solanum lycopersicum), Epinastic, Exhibits Tolerance to High Temperature Conditions. American Journal of Plant Sciences, 12, 487-497.

https://doi.org/10.4236/ajps.2021.124032

Received: March 1, 2021

Accepted: April 3, 2021

Published: April 6, 2021

Copyright $\odot 2021$ by author(s) and Scientific Research Publishing Inc. This work is licensed under the Creative Commons Attribution International License (CC BY 4.0).

http://creativecommons.org/licenses/by/4.0/ (c) (i) Open Access

\begin{abstract}
Above-optimal temperatures reduce yield in many crops, including tomato, largely because of the heat-sensitivity of their reproduction process. A full understanding of heat-stress (HS) response and thermotolerance of tomato reproduction is still lacking. Recently, using external application of the plant hormone ethylene, it was demonstrated that ethylene plays a role in heat-tolerance of tomato pollen (the male reproductive cells). In order to expand our understanding on involvement of ethylene in tomato pollen thermotolerance, we analyzed the response of wild type and ethylene-related tomato mutant plants to HS, at physiological and molecular levels. We report that mild chronic HS conditions highly reduce the number of viable and germinating pollen grains as well as the production of seeded fruits in wild type tomato plants, while no significant reduction was detected/observed in pollen quality, number of seeded fruits and seeds per fruit in plants of the ethylene over-producer mutant epinastic. Our findings suggest that ethylene is involved in thermotolerance of tomato reproduction, pointing to an effect on pollen viability and germination potential, highlighting candidate genes involved in pollen response to HS (like SIHSP17, SIHSP101, SIMBF1) and suggesting directions for further studies.
\end{abstract}

\section{Keywords}

Ethylene, Mild Chronic Heat Stress, Pollen Grains, Reproduction, Solanum lycopersicum, Thermotolerance 


\section{Introduction}

High temperature conditions constitute a major environmental stress, affecting yield and quality of many crops including vegetable crops. Heat stress (HS), defined as temperatures above the normal optimum needed for growth, is expected to increase in the coming years [1] [2], thus being an important factor to consider for maintaining food security. This problem is crucial in tomato because a significant proportion of production is achieved in greenhouses (to avoid insect-transmitted virus infections) where the daily mean temperatures are high, especially during the warmer seasons. We showed previously that developing pollen grains, the male reproductive cells, are most sensitive to both mild chronic and short-term acute HS conditions [3] [4] [5]. We found that heat-tolerant tomato genotypes, that exhibited higher yield under HS, produced also a larger number of high quality pollen grains under HS compared with the tested heatsensitive genotypes [3]. The physiological and molecular bases for pollen grains' HS response and heat tolerance (thermotolerance) are, however, still not fully understood [6] [7] [8].

Looking into pollen HS response, previous results from our laboratory revealed high HS regulation of heat-shock protein genes ( $H S P_{S}$, including small HSPS and HSP101), HS transcription factors (HSFs, including HSFA2) and additional factors that do not belong to the classical HS-responsive genes [9]. Involvement of ethylene in pollen HS response was suggested due to the high HSinduced expression, observed in developing tomato pollen grains, of several ethylene-responsive genes, including SIER24/ SIMBF1 (transcriptional coactivator multi-protein bridging factor; [9]). There is limited understanding, however, about ethylene involvement in pollen development and in pollen HS response [4] [5] [10] [11]. Available data from our laboratory indicate that external application of an ethylene releaser (ethephon) to tomato plants, prior to their exposure to HS conditions, increased significantly the number of germinating pollen grains per flower [11]. Involvement of ethylene in plant thermotolerance was previously reported in studies that dealt with vegetative tissues [12] [13] [14].

In the present study, in order to look into and further our understanding on the involvement of ethylene in pollen thermotolerance and in the production of seeded fruits under HS conditions, the response of tomato plants to HS conditions was investigated, in wild type (WT) and in two ethylene-related mutants, using physiological and molecular approaches.

\section{Materials and Methods}

The following mutants were used in the background of the tomato cultivar Micro-Tom [15] [16]: 1) Never ripe (Nr), a tomato mutant defective in the ethylene receptor (ETR3), a semi dominant ethylene receptor mutant [17]. 2) Epinastic (epi), being an ethylene over-producer [18]. The mutants were a gift from Dr. Peres (University of Sao Paulo, Brazil). The effect of mild chronic HS (MCHS) conditions was tested on flower ethylene production, pollen quality, production of seeded fruits and on expression levels of genes (known to be involved in ethy- 
lene production and signaling, as well as genes previously shown to be involved in plant thermotolerance) in isolated pollen grains.

For applying HS conditions, WT and mutant plants were grown in two temperature-controlled greenhouses at the Volcani Center in Rishon LeZion, Israel, under natural light conditions (day length of $13.5-14 \mathrm{~h}$ ) and day/night temperatures of $26 / 22^{\circ} \mathrm{C} \pm 2{ }^{\circ} \mathrm{C}$ for a month. Afterwards, one of the greenhouses was set to day/night temperatures of $32 / 26^{\circ} \mathrm{C} \pm 2{ }^{\circ} \mathrm{C}$ (designated MCHS) while the other greenhouse was maintained at $26 / 22^{\circ} \mathrm{C} \pm 2{ }^{\circ} \mathrm{C}$ (control conditions) and the plants were kept, in both greenhouses, for three additional months, with continuous production of flowers and fruits. These MCHS conditions were used in order to mimic the effect of summer conditions. Sampling of flowers and pollen grains was done from plants exposed to either "control" or "MCHS" conditions after at least 14 days from the time of applying the heat conditions.

Flower ethylene production was determined as described by Jegadeesan et al. [4]. Pollen quality was evaluated as described [4], by sampling mature pollen grains, to determine the number of viable and non-viable pollen grains. The population of viable pollen grains constituted of germinating and non-germinating pollen. All ethylene production and pollen quality results were the mean of at least three biological replicates. For ethylene measurements, flowers, $0.5 \mathrm{~g}$ per sample/replicate were collected/used. For pollen quality evaluation, each replicate consisted of pollen derived from at least eight flowers collected from four plants. For looking into the effect of the applied MCHS conditions on fruit and seed production, tomato fruits were harvested, from both greenhouses, at 110 days after transplanting and evaluated for fruit weight, percent of seeded fruits and number of seeds per fruit. Average number of red (ripe) fruits was 6 per plant in WT and ethylene mutants. Tomato fruits were collected from 16 plants, exposed to either "control" or "MCHS", and number of seeded fruits and average fruit weight were calculated. For each tomato genotype (WT, $N r$, epi) and treatment, seeds were collected from 40 fruits and average seed number per fruit was calculated.

For gene expression analyses, pollen grains were isolated from plants grown at "control" and "MCHS" conditions and maintained at $-80^{\circ} \mathrm{C}$ until use. Gene expression was evaluated using the Biomark HD system (Fluidigm, USA). Fluidigm 48.48 dynamic array chip was used following the manufacturer's ADP37 Fast GE (http://www.fluidigm.com/user-documents) protocol. Gene expression was calculated using the $2^{-\Delta \Delta c t}$ method, following normalization with the $18 \mathrm{~S}$ gene. Primer specificity and reference genes were validated prior to analysis. Heat map was generated using MultiExperiment Viewer, MeV v4.9 software, and expression profiles were obtained from $2^{-\Delta \Delta c t}$ data, where Hierarchical clustering of genes was based on Spearman correlation, allowing gene clustering according to their expression patterns.

\section{Results and Discussion}

Ethylene production results indicate that the amount of ethylene produced by 
flowers of the ethylene over-producer mutant, epi, was 2.9- and 1.5-fold higher than that produced by WT and $N r$ flowers, respectively (Figure 1(A)). The applied MCHS conditions caused a further increase in ethylene levels produced by epi flowers (Figure 1(A)). Mild chronic HS conditions caused a significant decrease in pollen quality of WT and $N r$ mutant plants as evidenced by reduction in the number of viable as well as germinating pollen grains, while epi plants showed no significant reduction in either the number of viable or germinating pollen grains, exhibiting thermotolerance at the level of pollen quality (Figure 1(B) and Figure 1(C), respectively). These results are in line and substantiate previous results from our laboratory, showing that external application of an ethylene-releasing substance, ethephon, prior to HS exposure, increased tomato pollen quality, pointing to involvement of ethylene in pollen thermotolerance [5] [11]. It should be noted that, under optimal conditions, total number of viable and germinating pollen grains per plant was lower in epi than in WT plants (Figure 1(B), Figure 1(C)).
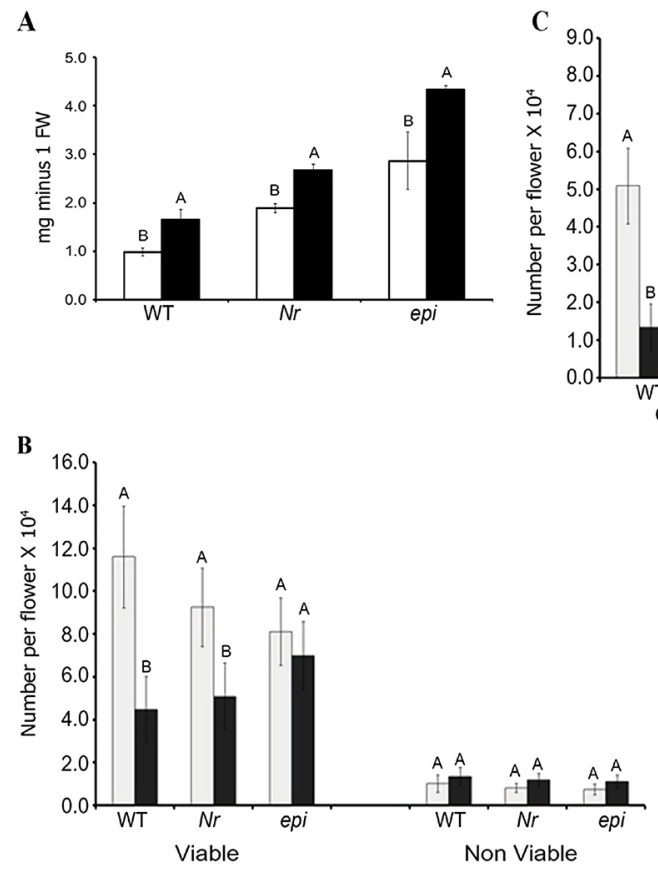
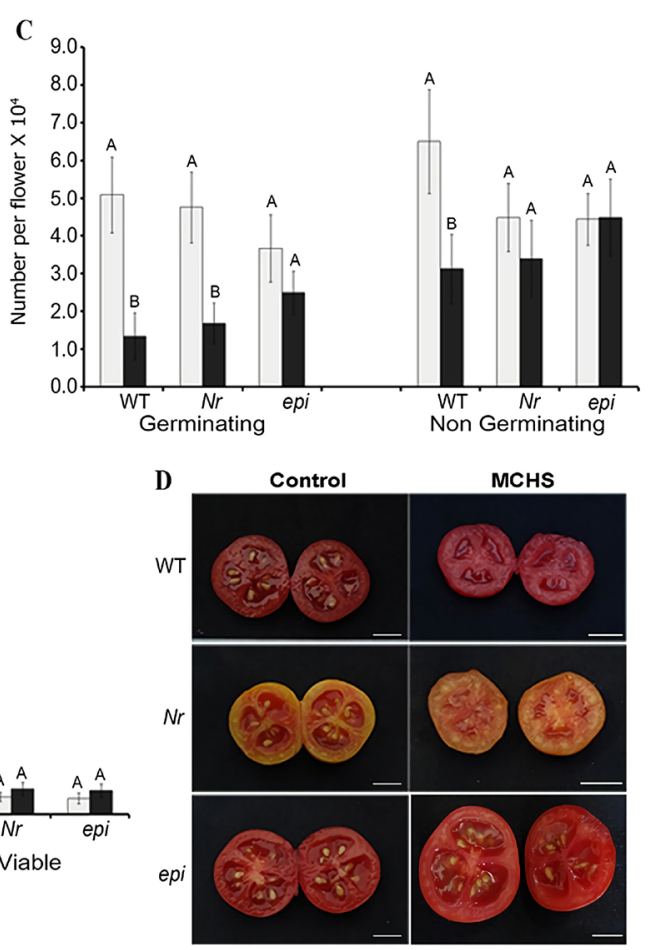

E
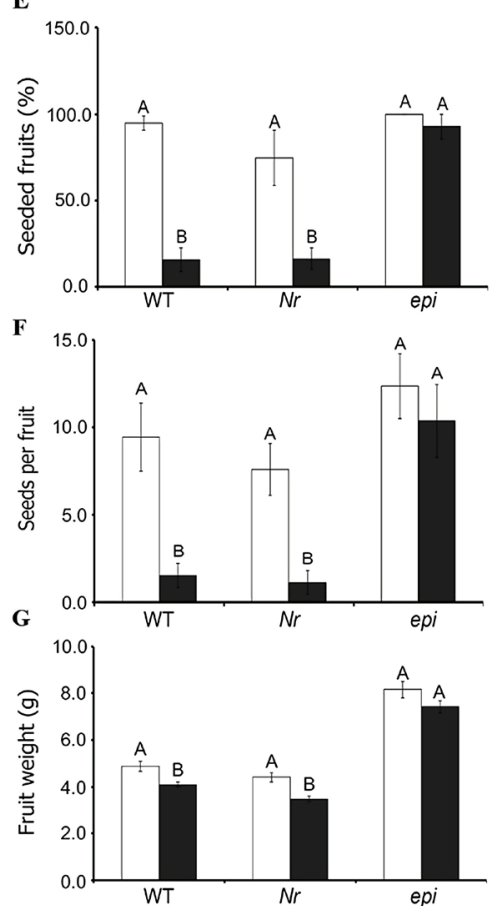

Figure 1. Effect of mild chronic HS on ethylene production, pollen quality and seeded-fruits production in wild type and ethylene-related mutant tomato plants. Ethylene production data (A) represent the amount of ethylene produced by flowers at anthesis, derived from tomato ( $c v$. Micro-Tom) plants exposed to either control (C, white bars, $26 / 22^{\circ} \mathrm{C} \pm 2{ }^{\circ} \mathrm{C}$ day/night temperatures) or mild chronic HS (MCHS; black bars, $32 / 26^{\circ} \mathrm{C} \pm 2^{\circ} \mathrm{C}$ day/night temperatures) conditions. Ethylene production was evaluated as described by Jegadeesan et al. [4]. Results are presented as mean values \pm SE of three biological replicates. Pollen quality was evaluated by collecting mature pollen grains from wild type (WT) and ethylene-related mutant plants ( $N r$ and epi), exposed to either control or MCHS conditions. Pollen quality data are presented as mean values \pm SE (using three biological replicates) of number of viable, non viable (B), germinating and non germinating (C) pollen grains per flower. Representative fruits of WT, Nr and epi exposed to either control or MCHS are presented in (D). Percent of seeded fruits (E), number of seeds per fruit (F) and fruit weight $(G)$ were evaluated and data are presented as mean values \pm SE. Different letters indicate statistical significance by Tukey HSD test ( $p$-value $\leq 0.05$ ) between treatments $(\mathrm{C}$ and MCHS). Scale bars $=1 \mathrm{~cm}$. 
The outcome of successful fertilization is the production of seeded fruits. Representative pictures of fruits produced under optimal and MCHS conditions in WT, $N r$ and epi plants are presented in Figure 1(D). Under optimal growth conditions ("control") percent seeded fruits and number of seeds per fruit in epi plants were comparable to those in WT plants, indicating that the number of pollen grains produced by epi was sufficient for fulfilling the plant's reproductive potential (Figure 1(E), Figure 1(F)). Mild chronic HS conditions highly reduced the production of seeded fruits in both WT and Nr plants, while in epi plants there was no reduction in either the percentage of seeded fruits or the average number of seeds per fruit (Figure 1(E) and Figure 1(F), respectively). Fruit weight was also maintained in epi plants under HS (Figure 1(G)).

To characterize the effect of epi on tomato pollen HS response at the molecular level, we used a high throughput gene expression analysis (Biomark HD system, Fluidigm 48.48 dynamic array chip, Fluidigm, USA) as indicated in "Materials and Methods". Details on the Fluidigm array gene expression analyses and list of primers are given in Supplementary Table S1. Gene expression was calculated using the $2^{-\Delta \Delta c t}$ method, following normalization with the $18 \mathrm{~S}$ gene (a reference gene; [4]). Heat map was generated using MultiExperiment Viewer, $\mathrm{MeV}$ v4.9 software, and expression profiles were obtained from $2^{-\Delta \Delta c t}$ data, where Hierarchical clustering of genes was based on Spearman correlation, allowing gene clustering according to their expression patterns. The list of genes used included: 1) Ethylene-biosynthesis and ethylene-signaling genes found by us recently to express in tomato pollen grains [4]. 2) Classical heat-stress genes (like HSPs and HSFS) known to play an important role in plant thermotolerance [19] [20] [21]. 3) Genes coding for reactive-oxygen species scavengers (like superoxide dismutase, ascorbate peroxidase) and 4) Translation initiation factors. The list of all gene primers is presented in Supplementary Table S1.

Gene expression results are presented as a heat-map (Figure 2(A)) highlighting a small group of genes exhibiting high and significant HS-upregulation in pollen of the ethylene overproducer mutant epi (Figure 2(B)). These genes include SIER21 (an ethylene-responsive member of the HPS7O family; [22]), SIHSP101 and $S I H S P 17$ (suggested previously in numerous studies to play a role in plant thermotolerance; [8] [23]) as well as SIMBF1 (shown in Arabidopsis to function upstream of salicylic acid and ethylene; [24] [25]) (Figure 2(B)).

Taken together, the data presented in this work, and schematically summarized in Figure 3, support the hypothesis that ethylene contributes to thermotolerance of tomato reproduction, as evidenced by the relative high number of germinating pollen grains, seeded fruits and seeds per fruit, detected in plants/ flowers of epi, that were exposed to MCHS conditions. Furthermore, the relative high expression levels of HSPs (SIER21/SIHSP70, SIHSP101, SIHSP17) as well as $S I M B F 1$, detected in pollen of epi plants exposed to MCHS, may protect pollen proteins from HS-induced damages and contribute to epi pollen thermotolerance (during pollen development and germination). Further studies are needed in order to better characterize the role of SIMBF1 in pollen HS response and 

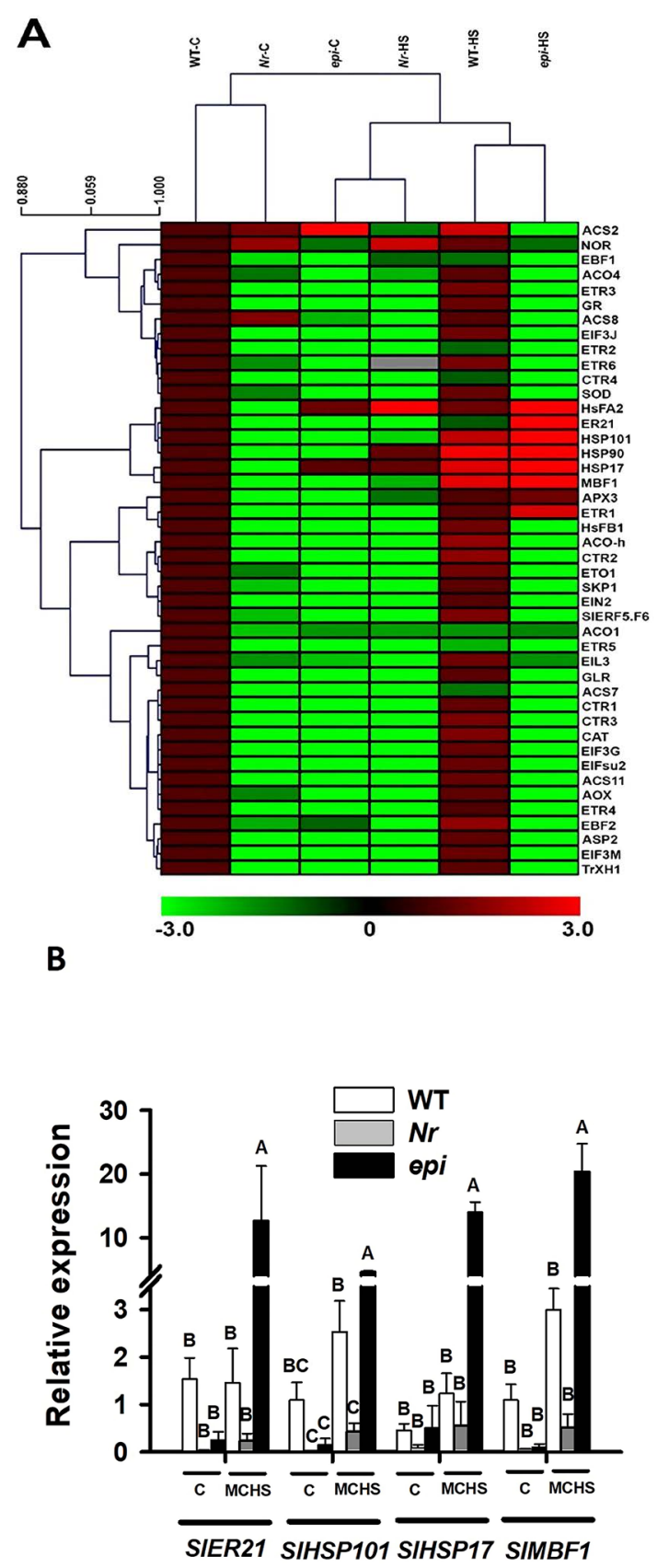

Figure 2. Effect of mild chronic HS on gene expression of pollen derived from WT and ethylene mutant plants. Gene expression was evaluated using the Fluidigm dynamic array chip. Pollen grains were isolated from flowers at anthesis, derived from plants that were exposed to either control $\left(\mathrm{C}, 26 / 22^{\circ} \mathrm{C} \pm 2^{\circ} \mathrm{C}\right.$ day/night temperatures) or mild chronic HS (MCHS, $32 / 26^{\circ} \mathrm{C} \pm 2^{\circ} \mathrm{C}$ day/night temperatures) conditions as described in [4] [26]. Gene expression was calculated as detailed in "Materials and Methods" section. Heat map and hierarchical clustering of genes was done according to gene expression patterns as detailed in "Materials and Methods" (A). Fold change was calculated relative to expression values in pollen of WT plants at control conditions. Expression profiles of specific genes are given (B). Expression data are the means $( \pm \mathrm{SE})$ of three biological replicates, each replicate containing pollen grains derived from 40 - 60 flowers/flower buds. For each gene, bars with different letters are significantly different by Tukey HSD test ( $p$-value $\leq$ $0.05)$ across lines and treatments. 


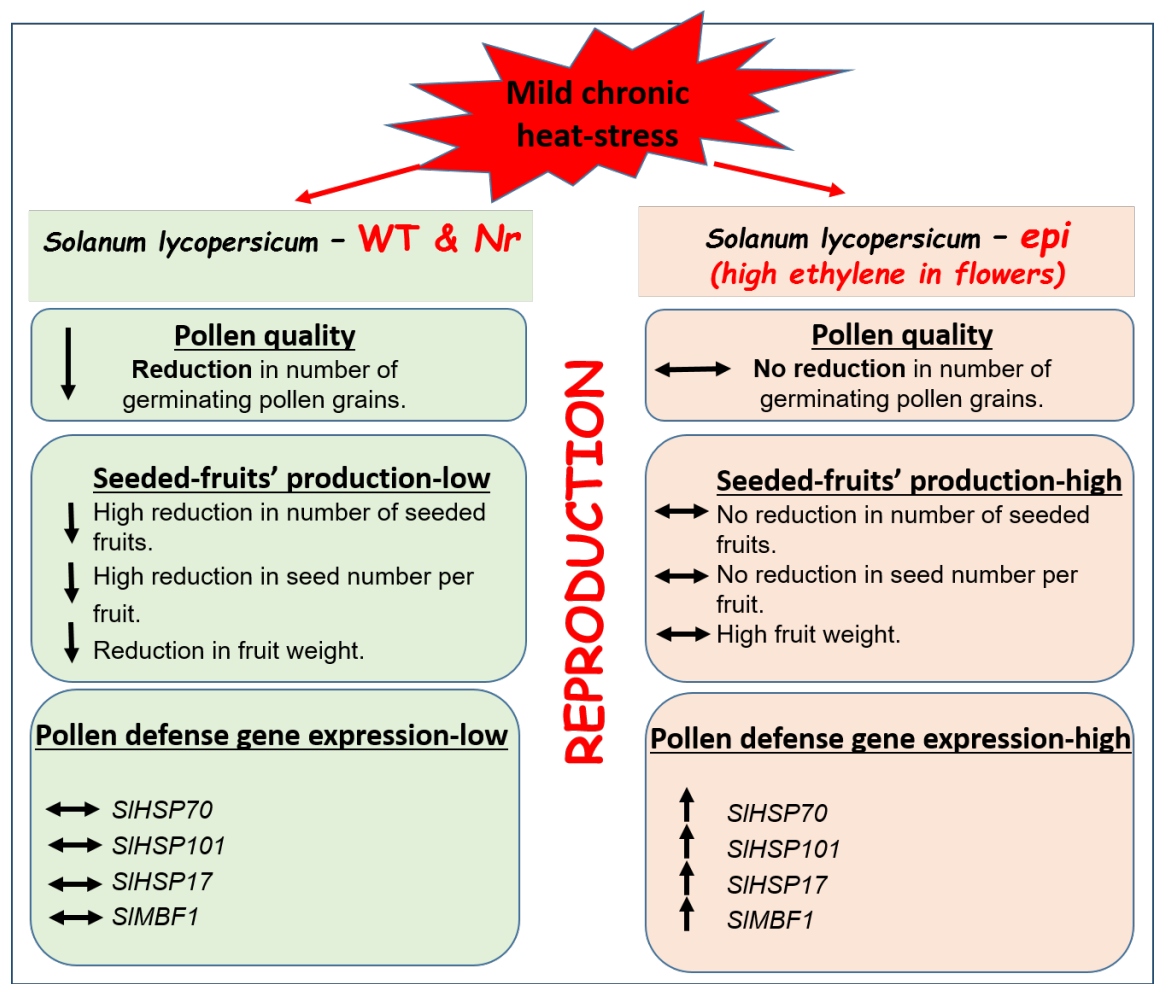

Figure 3. A scheme summarizing the effect of the epi mutation on tomato pollen quality, production of seeded fruits and expression of thermotolerance-associated genes under mild chronic HS conditions. Under mild chronic HS conditions, the ethylene-overproducer epi mutant plants of tomato ( $c v$. Micro-Tom) exhibit relative high number of germinating pollen grains, seeded-fruits per plant and seeds per fruit, as compared to wild type plants. In addition, relative high expression levels of heat-tolerance-associated genes (SIHSP70/SIER21, SIMBF1, SIHSP101 and SIHSP17) are detected in pollen grains of epi plants under mild chronic HS conditions, suggesting their involvement in pollen thermotolerance.

thermotolerance and identify additional regulators, downstream to epi, that may activate pollen thermotolerance mechanisms. It should be noted that that HS conditions applied in the current study were MCHS, lasting for at least 14 days prior to pollen collection and may have imposed heat acclimation and activation of acclimation mechanisms.

The use of tomato ethylene mutants is suggested as a valuable experimental tool for further research aimed at increasing our understanding on the involvement of ethylene in the heat-response and thermotolerance of tomato reproduction process (including pollen development and germination as well as the HS response of the female tissues) and fruit-setting.

\section{Funding}

This work was supported by grant agreement number 2610970 from the Chief Scientist of The Ministry of Agriculture and Rural Development, Israel. Sridharan Jegadeesan was supported by the European Commission, the European Marie-Curie International training network "Solanaceae pollen thermotolerance 
SPOT-ITN", grant agreement number 289220.

\section{Conflicts of Interest}

No potential conflicts of interest were disclosed.

\section{References}

[1] Mittler, R., Finka, A. and Goloubinoff, P. (2012) How Do Plants Feel the Heat? Trends in Biochemical Sciences, 37, 118-125. https://doi.org/10.1016/j.tibs.2011.11.007

[2] Bokszczanin, K.L. and Fragkostefanakis, S. (2013) Perspectives on Deciphering Mechanisms Underlying Plant Heat Stress Response and Thermotolerance. Frontiers in Plant Science, 4, 315. https://doi.org/10.3389/fpls.2013.00315

[3] Firon, N., Shaked, R., Peet, M.M., Pharr, D.M., Zamski, E., Rosenfeld, K., Althan, L. and Pressman, E. (2006) Pollen Grains of Heat Tolerant Tomato Cultivars Retain Higher Carbohydrate Concentration under Heat Stress Conditions. Scientia Horticulturae, 109, 212-217. https://doi.org/10.1016/j.scienta.2006.03.007

[4] Jegadeesan, S., Beery, A., Altahan, L., Meir, S., Pressman, E. and Firon, N. (2018) Ethylene Production and Signaling in Tomato (Solanum lycopersicum) Pollen Grains Is Responsive to Heat Stress Conditions. Plant Reproduction, 31, 367-383. https://doi.org/10.1007/s00497-018-0339-0

[5] Jegadeesan, S., Chaturvedi, P., Ghatak, A., Pressman, E., Meir, S., Faigenboim, A., Rutley, N., Beery, A., Harel, A., Weckwerth, W. and Firon, N. (2018) Proteomics of Heat-Stress and Ethylene Mediated Thermotolerance Mechanisms in Tomato Pollen Grains. Frontiers in Plant Science, 9, 1558. https://doi.org/10.3389/fpls.2018.01558

[6] Zinn, K.E., Tunc-Ozdemir, M. and Harper, J.F. (2010) Temperature Stress and Plant Sexual Reproduction: Uncovering the Weakest Links. Journal of Experimental Botany, 61, 1959-1968. https://doi.org/10.1093/jxb/erq053

[7] Burke, J.J. and Chen, J. (2015) Enhancement of Reproductive Heat Tolerance in Plants. PLoS ONE, 10, e0122933. https://doi.org/10.1371/journal.pone.0122933

[8] Rieu, I., Twell, D. and Firon, N. (2017) Pollen Development at High Temperature: From Acclimation to Collapse. Plant Physiology, 173, 1967-1976. https://doi.org/10.1104/pp.16.01644

[9] Frank, G., Pressman, E., Ophir, R., Althan, L., Shaked, R., Freedman, M., Shen, S. and Firon, N. (2009) Transcriptional Profiling of Maturing Tomato (Solanum lycopersicum L.) Microspores Reveals the Involvement of Heat Shock Proteins, ROS Scavengers, Hormones, and Sugars in the Heat Stress Response. Journal of Experimental Botany, 60, 3891-3908. https://doi.org/10.1093/jxb/erp234

[10] De la Torre, F., Del Carmen Rodríguez-Gacio, M. and Matilla, A.J. (2006) How Ethylene Works in the Reproductive Organs of Higher Plants: A Signaling Update from the Third Millennium. Plant Signaling \& Behavior, 1, 231-242.

https://doi.org/10.4161/psb.1.5.3389

[11] Firon, N., Pressman, E., Meir, S., Khoury, R. and Altahan, L. (2012) Ethylene Is Involved in Maintaining Tomato (Solanum lycopersicum) Pollen Quality under HeatStress Conditions. AoB Plants, 2012, pls024. https://doi.org/10.1093/aobpla/pls024

[12] Larkindale, J. and Knight, M.R. (2002) Protection against Heat Stress-Induced Oxidative Damage in Arabidopsis Involves Calcium, Abscisic Acid, Ethylene, and Salicylic Acid. Plant Physiology, 128, 682-695. https://doi.org/10.1104/pp.010320 
[13] Larkindale, J. and Huang, B. (2005) Effects of Abscisic Acid, Salicylic Acid, Ethylene and Hydrogen Peroxide in Thermotolerance and Recovery for Creeping Bentgrass. Plant Growth Regulation, 47, 17-28. https://doi.org/10.1007/s10725-005-1536-Z

[14] Larkindale, J., Hall, J.D., Knight, M.R. and Vierling, E. (2005) Heat Stress Phenotypes of Arabidopsis Mutants Implicate Multiple Signaling Pathways in the Acquisition of Thermotolerance. Plant Physiology, 138, 882-897.

https://doi.org/10.1104/pp.105.062257

[15] Meissner, R., Jacobson, Y., Melamed, S., Levyatuv, S., Shalev, G., Ashri, A., Elkind, Y. and Levy, A.A. (1997) New Model System for Tomato Genetics. The Plant Journal, 12, 1465-1472. https://doi.org/10.1046/j.1365-313x.1997.12061465.x

[16] Carvalho, R.F., Campos, M.L., Pino, L.E., Crestana, S.L., Zsogon, A., Lima, J.E., et al. (2011) Convergence of Developmental Mutants into Single Tomato Model System: "Micro-Tom" as an Effective Toolkit for Plant Development Research. Plant Methods, 7, 18. https://doi.org/10.1186/1746-4811-7-18

[17] Klee, H.J. (2004) Ethylene Signal Transduction. Moving beyond Arabidopsis. Plant Physiology, 135, 660-667. https://doi.org/10.1104/pp.104.040998

[18] Barry, C.S., Fox, E.A., Yen, H., Lee, S., Ying, T., Grierson, D., et al. (2001) Analysis of the Ethylene Response in the Epinastic Mutant of Tomato. Plant Physiology, 127, 58-66. https://doi.org/10.1104/pp.127.1.58

[19] Kotak, S., Larkindale, J., Lee, U., von Koskull-Döring, P., Vierling, E. and Scharf, K.D. (2007) Complexity of the Heat Stress Response in Plants. Current Opinion in Plant Biology, 10, 310-316. https://doi.org/10.1016/j.pbi.2007.04.011

[20] McLoughlin, F., Kim, M., Marshall, R.S., Vierstra, R.D. and Vierling, E. (2019) HSP101 Interacts with the Proteasome and Promotes the Clearance of Ubiquitylated Protein Aggregates. Plant Physiology, 180, 1829-1847. https://doi.org/10.1104/pp.19.00263

[21] Waters, E.R. and Vierling, E. (2020) Plant Small Heat Shock Proteins-Evolutionary and Functional Diversity. New Phytologist, 227, 24-37.

https://doi.org/10.1111/nph.16536

[22] Fragkostefanakis, S., Simm, S., Paul, P., Bublak, D., Scharf, K.D. and Schleiff, E. (2015) Chaperone Network Composition in Solanum lycopersicum Explored by Transcriptome Profiling and Microarray Meta-Analysis. Plant, Cell \& Environment, 38, 693-709. https://doi.org/10.1111/pce.12426

[23] Jaimes-Miranda, F. and Chavez Montes, R.A. (2020) The Plant MBF1 Protein Family: A Bridge between Stress and Transcription. Journal of Experimental Botany, 71, 1782-1791. https://doi.org/10.1093/jxb/erz525

[24] Suzuki, N., Rizhsky, L., Liang, H., Shuman, J., Shulaev, V. and Mittler, R. (2005) Enhanced Tolerance to Environmental Stress in Transgenic Plants Expressing the Transcriptional Coactivator Multiprotein Bridging Factor 1c. Plant Physiology, 139, 1313-1322. https://doi.org/10.1104/pp.105.070110

[25] Suzuki, N., Bajad, S., Shuman, J., Shulaev, V. and Mittler, R. (2008) The Transcriptional Co-Activator MBF1c Is a Key Regulator of Thermotolerance in Arabidopsis thaliana. Journal of Biological Chemistry, 283, 9269-9275.

https://doi.org/10.1074/jbc.M709187200

[26] Pressman, E., Harel, D., Zamski, E., Shaked, R., Althan, L., Rosenfeld, K. and Firon, N. (2006) The Effect of High Temperatures on the Expression and Activity of Sucrose-Cleaving Enzymes during Tomato (Solanum lycopersicum) Anther Development. The Journal of Horticultural Science and Biotechnology, 81, 341-348. https://doi.org/10.1080/14620316.2006.11512071 


\section{Supplementary}

Supplementary Table S1. Details of the Fluidigm array gene expression analyses and list of primers.

\begin{tabular}{|c|c|c|c|c|}
\hline Solyc ID & Gene name & Description & Forward primer & Reverse primer \\
\hline \multicolumn{5}{|c|}{ Ethylene related genes } \\
\hline Solyc01g095080 & SlACS2 & $\begin{array}{l}1 \text { aminocyclopropane } \\
\text { carboxylate synthase } 2\end{array}$ & CGATGCATTTTTAGTACCTTCACC & CGATGCATTTTTAGTACCTTCACC \\
\hline Solyc02g063540 & SlACS7 & $\begin{array}{l}1 \text { aminocyclopropane } \\
\text { carboxylate synthase } 7\end{array}$ & CGTGTCTGAAAATCAAAAGAGG & TGTCTCATATCCACCCAACAAA \\
\hline Solyc03g043890 & SlACS8 & $\begin{array}{l}1 \text { aminocyclopropane } \\
\text { carboxylate synthase } 8\end{array}$ & GCGCTACTTCCGCAAATGAA & TTGGAACTATTTCCGCCCCG \\
\hline Solyc07g049530 & SlACO1 & $\begin{array}{l}1 \text { aminocyclopropane } \\
\text { carboxylate oxidase } 1\end{array}$ & ACAAACAGACGGGACACGAA & СCTCTGCCTCTTTTTCAACC \\
\hline Solyc02g081190 & SlACO4 & $\begin{array}{l}1 \text { aminocyclopropane } \\
\text { carboxylate oxidase } 4\end{array}$ & TGATTGAGAAGACAGAAGAGGACA & GGAATTTGAGACCTGCATACAAC \\
\hline Solyc12g011330 & SlETR1 & ethylene receptor1 & TTCAAGGATTAAAGGTTTTGGTGAT & ATCACATCCAAGGTGTGTAAGCA \\
\hline Solyc07g056580 & SIETR2 & ethylene receptor2 & GCCGTCAGTGTACATGAGAAATTT & AGTTTTCTTTTGTCACTTGGTCAGTGT \\
\hline Solyc09g075440 & SlETR3 & ethylene receptor/NR & AGGGAACCACTGTCACGTTTG & CTCTGGGAGGCATAGGTAGCA \\
\hline Solyc06g053710 & SlETR4 & ethylene receptor4 & GGTAATCCCAAATCCAGAAGGTTT & CAATTGATGGCCGCAGTTG \\
\hline Solyc11g006180 & SlETR5 & ethylene receptor5 & AGTCATCTTTTAGGAAACGCATGTT & AGGAGTACATGAAGGCCTCTGAA \\
\hline Solyc09g089610 & SlETR6 & ethylene receptor6 & ATTCCAAAGGCAGCCGTTAA & GGATGTGGATATGTGGGATTAGAAG \\
\hline Solyc09g007870 & SIEIN2 & Ethylene-insensitive 2 & AGA TGC GAG AGC TCA ATG GT & GAC CAC CTG CCC TTA GTG AA \\
\hline Solyc01g096810 & SlEIL3 & EIN3-lke gene 3 & GATGTCGCGTGCACAAGATG & GCACGAAGATTGTCCGAAGC \\
\hline Solyc12g009560 & SlEBF1 & & TCTCGCTTGCTGTCATTGGT & GACTGGAGGCCTTGAGCATT \\
\hline Solyc08g060810 & SlEBF2 & & GCAACAGATGTCCGACTTGC & TCAGTCACACCACGGATTGG \\
\hline Solyc09g055310 & SlETO1 & Ethylene over producer 1 & GCAAGGGCAGAGGTTTTTGG & GGGATCCAATCTGCTGGCAT \\
\hline Solyc12g005960 & SlERF5.F6 & Ethylene response factor & TGCGCGTGCATTGTGTAAAA & CCACCACAGAAGACGACGAA \\
\hline Solyc04g011440 & SlER21 & $\begin{array}{l}\text { ethylene induced heat } \\
\text { shock protein }\end{array}$ & AGGACCAGCGATCGGAATTG & CTCCAATCAACCGCTCCGTA \\
\hline Solyc01g104740 & SlMBF1 & $\begin{array}{l}\text { Multi protein bridging } \\
\text { factor/ethylene response } \\
\text { protein } 21\end{array}$ & CCA AGA CCT GAA GGA TCC AA & CCG CCT TCT TAT TCA AAC CA \\
\hline Solyc10g006880 & SINOR & Non ripening & TCCATGGGAACTCCCTGCTA & GATGTTGCAGCCCGATTTGG \\
\hline \multicolumn{5}{|l|}{ ROS scavangers } \\
\hline Solyc09g007270 & SIAPX3 & Ascorbate peroxidase 3 & CCGCCCTCTAGTCGAGAAAT & AGAACCAGACTGATCTCCAGAGA \\
\hline Solyc04g082460 & SICAT & Calatase3 & CTGATACCCAGAGACACCGC & TGACCTCTTCATCACGGTGC \\
\hline Solyc06g067960 & SIGR & Glutaredoxin family protein & CGTTTTGCAGCCTACCCTCT & GTGTCCGGATCACTAGGCAC \\
\hline Solyc08g075540 & SlAOX & Alternative oxidase & GTTGTCTTGGTTGTTCGGGC & ATACCCAAGTGGTGCTGGTG \\
\hline Solyc02g084710 & SITRXH1 & Thioredoxin H-type 1 & GTGTGGTCCCTGCAAGTTCA & CTCCACGGCCCAATCAGTAG \\
\hline Solyc09g091840 & SlGR & $\begin{array}{l}\text { Glutathione-disulfide } \\
\text { reductase }\end{array}$ & ACCTGAAATCATGCAGGGCA & TGAAGAAATGCGCCTCGACT \\
\hline HSFs and HSPs & & & & \\
\hline
\end{tabular}




\section{Continued}

\begin{tabular}{|c|c|c|c|c|}
\hline Solyc08g062960 & SlHsFA2 & heat stress factor $\mathrm{A} 2$ & TTCCACCACATTGTTGCCTA & GCAAGCACCAGATCCTTGTT \\
\hline Solyc03g115230 & SlHSP101 & Heat shock protein 101 & ACATAGATGCTGGACGTGGC & AGCATCATTCCTTGGCCCAT \\
\hline Solyc03g007890 & SlHSP17 & Heat shock protein 17 & AAGGTCCGGCACCAAAGAAT & CTCCGCTACGAGGTAAGCAG \\
\hline Solyc06g036290 & SlHSP90 & Heat shock protein 90 & GTTCGAGAGCTTGACGGACA & TCATGCCAATACCGCTGTCA \\
\hline Solyc02g090820 & SlHsFB1 & heat stress factor B1 & GTCCCAGTTCACGGACTTGT & TTGGCTCATGATACGGTTGA \\
\hline \multicolumn{5}{|c|}{ Translation initiation factors } \\
\hline Solyc02g089070 & SIEIF3M & $\begin{array}{c}\text { Eukaryotic translation } \\
\text { initiation factor } 3 \text { subunit M }\end{array}$ & GCAAGATCTCCGCACGAAAC & TGCTAAACCTTGCACTGCCT \\
\hline Solyc02g079060 & SIEIF3J & $\begin{array}{l}\text { Eukaryotic translation } \\
\text { initiation factor } 3 \text { subunit J }\end{array}$ & CACGGCTGAATTGTTTGCCA & GCTTTTCTCAAACGGTCGCA \\
\hline Solyc03g120010 & SlEIF3su2 & $\begin{array}{l}\text { Eukaryotic translation } \\
\text { initiation factor } 3 \text { subunit } 2\end{array}$ & TCCACAGCAAACGGGTCTAC & TTCTGCTCCACACCATCGAC \\
\hline Solyc08g074790 & SIEIF3G & $\begin{array}{l}\text { Eukaryotic translation } \\
\text { initiation factor } 3 \text { subunit } 4\end{array}$ & GCAGGGGCTGTTCTTATGGT & СССТTGATGGTGGCСТATCC \\
\hline X51576 & SI18S-200bp & $18 \mathrm{~S}$ ribosomal gene & CTTCTGGAAGGGATGCATTT & CTCCGGAATCGAACCCTAAT \\
\hline
\end{tabular}

The Fluidigm 48.48 dynamic array chip was used following the manufacturer's ADP37 Fast GE (http://www.fluidigm.com/user-documents) protocol, which allows 2304 simultaneous real time PCR gene expression. Primer specificity and reference genes were validated prior to analysis. Pre-amplification of cDNA was performed on $1.25 \mu \mathrm{l}$ of $50 \mathrm{ng} \cdot \mu \mathrm{l}^{-1}$ samples using Fluidigm PreAmp Master Mix (Fluidigm, PN 1005581), and $2.7 \mu \mathrm{l}$ of each pre-amplified cDNA was mixed with $3 \mu \mathrm{l}$ of SsoFast EvaGReen Supermix with Low Rox (Bio-Rad, PN 1725211) and 0.3 $\mu \mathrm{l}$ of 20X Binding Dye Sample Loading Reagent (Fluidigm, PN 1001388). Individual primer pairs $(50 \mu \mathrm{M})$ in a $1.08 \mu \mathrm{l}$ volume mixed with $3 \mu \mathrm{l}$ Assay Loading Reagent (Fluidigm, PN 85000736) and 1.92 $\mu \mathrm{l}$ of Low TE. Total $5 \mu \mathrm{l}$ of each sample mix or each assay mix was then pipetted into individual sample inlet in the 48.48 Dynamic Array chip, and a (IFC) controller MX (Fluidigm) to prime the chip. The loaded chip was placed in the BioMark system for PCR at $95^{\circ} \mathrm{C}$ for $10 \mathrm{~min}$, followed by $40 \mathrm{cycles}$ at $95^{\circ} \mathrm{C}$ for $15 \mathrm{sec}$ and $60^{\circ} \mathrm{C}$ for $1 \mathrm{~min}$. Following each reaction in a specific inlet, the PCR amplification curve was generated and the chip was imaged. The dynamic array raw data was analyzed with the Fluidigm Real-Time PCR Analysis software. The gene expression was calculated using the $2^{-\Delta \Delta c t}$ method, following normalization with $18 \mathrm{~S}$ gene.

\section{Abbreviations}

HS, Heat-stress;

HSF, Heat-stress factor;

HSP, Heat shock/stress protein;

MCHS, Mild chronic heat-stress;

MBF1, Multiprotein bridging factor1. 